\title{
QUANTITATIVE METHOD FOR EVALUATING APPLICABILITY OF DESIGNED REINFORCEMENT PATTERN
}

\author{
Aleksandar Milajić, Aleksandar Prokić, Dejan Beljaković, Goran Pejičić
}

Original scientific paper Methods for optimal design of the reinforced concrete structures presented in literature usually do not consider detailed reinforcement pattern, or if they do, it is either too generalized or the optimal solution is always the one with the lowest amount of the reinforcement, disregarding its applicability in reality, at the building site. In order to develop adequate apparatus for numerical estimation and easier choice of the most appropriate solution from the practical point of view, a field research was conducted at the building sites for obtaining data about realistic time needed for placing and fixing reinforcement in different formations. Obtained results were normalized and functional correlations between them were established. Testing results confirmed that proposed approach can help a designer to choose the most applicable solution among several theoretically acceptable ones and that the developed reinforcement pattern coefficient can be successfully used in solving complex optimization problems.

Keywords: applicability evaluation; optimization; reinforcement pattern; reinforced concrete structures

\section{Kvantitativna metoda za ocjenu primjenljivosti projektirane sheme armiranja}

Izvorni znanstveni članak U metodama optimalnog projektiranja armiranobetonskih konstrukcija koje se mogu naći u literaturi obično se ne razmatra detaljna shema armiranja ili je, ako se i razmatra, to ili previše uopćeno, ili se za optimalno rješenje uvijek usvaja ono s najmanjom količinom armature, bez obzira na njegovu primjenljivost u stvarnosti, tj. na gradilištu. U cilju razvoja odgovarajućeg matematičkog aparata za numeričku ocjenu i lakši odabir odgovarajućeg rješenja s praktične točke gledišta, provedeno je terensko istraživanje na gradilištima kako bi se prikupili podaci o realnom vremenu potrebnom za postavljanje i fiksiranje različitih rasporeda armature. Prikupljeni rezultati su normalizirani i između njih su uspostavljene funkcionalne korelacije. Rezultati testiranja su potvrdili da prikazani pristup može pomoći projektantu kod odabira najprimjenljivijeg rješenja između nekoliko teorijski prihvatljivih te da se izvedeni koeficijent sheme armiranja može uspješno primijeniti pri rješavanju složenih optimizacijskih problema.

Ključne riječi: armiranobetonske konstrukcije; ocjena primjenljivosti; optimiziranje; shema armiranja

\section{Introduction}

During the past two decades, rapid advances in information technology and computing power have improved the accuracy and capabilities of optimization methods and finding solutions for engineering problems that used to be considered hard or even impossible for solving. Unfortunately, great number of optimization methods in the field of civil engineering has not found implementation in practice, mainly because the given tasks were treated only as mathematical problems, disregarding practical point of view, i.e. applicability of obtained optimal solution in reality. Since the aim of any optimization method is developing methodology that would successfully imitate human reasoning and decisionmaking process, it is necessary to transform different rules of thumb into mathematical form and to establish new sets of numerical criteria that would favourize the same solutions that would be chosen by an expert, i.e. an experienced designer.

One of such problems is optimal design of the reinforced concrete structures. In traditional design procedure, complete solution of this task includes dimensions and detailed reinforcement patterns for all cross sections, so it can be directly implemented at the building site. The main difficulty in developing appropriate optimization method for solving this problem is large number of possibilities in choosing reinforcement bars diameters and patterns, especially if one considers possibilities of combining different diameters and forming bundles.

In all methods proposed in the literature, basic criterion for choosing the reinforcement pattern is minimal amount of steel, regardless of its applicability at the construction site. This means that a simple and easily achievable solution would be eliminated just because it is the 'second best', even if its total amount of the steel is infinitesimally larger than in pattern that requires less reinforcement but is much more complicated, which would be automatically accepted as the optimum. Besides that, the same set of reinforcing bars can be placed in a given cross section in several different patterns that would all have approximately equal bearing capacity but will remarkably vary considering possibility of efficient and exact placing and fixing.

Purpose of this paper is an attempt to abridge a gap between theory and practice in the field of optimal design of the reinforced concrete structures and to enable researchers and practitioners to assess obtained solutions from the practical point of view. Proposed methodology can be easily included in different optimization algorithms and methods as well as implemented in similar researches and optimum design tools. The second section of the paper includes problem definition and short overview of insofar researches and results available in the literature. The third section describes the field research conducted on building sites in order to find out the real time needed for placing and fixing different reinforcement patterns. Obtained data were analysed and the functional correlations between different reinforcement features were developed. Based on these findings, coefficients for numerical assessment of different reinforcement patterns were developed and tested. Proposed methodology is illustrated by two examples presented in the fourth section, showing that developed reinforcement pattern coefficient can successfully be used as an optimality 
criterion in decision-making process when there are several feasible patterns with approximately same amount of steel. Concluding remarks are given in the last section.

\section{Problem definition}

Numerical methods for optimal design of the reinforced concrete structures are based on finding crosssectional dimensions and corresponding reinforcement that would result in minimal price of a given structure. Therefore, mathematical model of this optimization problem can be formulated as follows:

$\min F=W_{\mathrm{c}} p_{\mathrm{c}}+A_{\mathrm{f}} p_{\mathrm{f}}+W_{\mathrm{s}} p_{\mathrm{s}}$,

where $W_{\mathrm{c}}, A_{\mathrm{f}}$ and $W_{\mathrm{s}}$ are amounts of concrete, formwork and reinforcement given in $\mathrm{m}^{3}, \mathrm{~m}^{2}$ and $\mathrm{kg}$, respectively, while $p_{\mathrm{c}}, p_{\mathrm{f}}$ and $p_{\mathrm{r}}$ are unit prices including the price of material as well as the price of work.

The main difficulty in solving this task is the applicability of obtained optimal solution in reality. Numerous researchers based their methods on finding optimal cross-sectional dimensions and necessary amount of steel without further consideration of the reinforcement pattern $[1 \div 7]$. Although numerically correct, these solutions are only partially complete because it is still left to a designer to choose the reinforcement bars and their placing pattern within the obtained optimal cross section. This task can be quite demanding considering the number of different bar diameters, their possible combinations and possibility of making bundles consisting of two to four same or different bars. Besides that, taking all the reinforcement spacing rules and requirements into account can rise the number of variables from two (crosssectional dimensions) to as much as $16[8,9]$. In order to simplify this problem, some authors limited the number of rows to one $[10,11]$ or two [12], the number of bars per row to four [10] or five [12] or assumed that all bars have the same diameter $[13,14]$. Another group of solutions, especially in the field of heuristic optimization methods $[15 \div 23]$ is based on even more simplified approach in which the reinforcement pattern is chosen from previously developed data base of possible bars formations created with similar limitations and assumptions as in the previous group. In this case, the optimality criterion is either bearing capacity or minimal amount of steel.

All of the above mentioned approaches and assumptions are acceptable for relatively small cross sections $(b \leq 35 \mathrm{~cm})$ but not for wider cross sections and especially for very narrow cross sections with large amount of the reinforcement (such as T-shaped section). Besides that, none of the mentioned approaches considers possibility of making bundles, while only few of them deal with possibility of combining different bar diameters.

Another problem with described approaches is the fact that all optimization methods are based on using computer. While an experienced engineer would easily make a choice between similar reinforcement patterns with approximately same bearing capacity or amount of steel, the computer would always opt for the one that would result in mathematical minimum of a given criterion, regardless of its applicability.
One possible relevant criterion for assessing applicability of any given reinforcement pattern in reality might be the time needed for its placing at the building site. However, productivity rates for man-hours calculation for in-situ reinforcement fixing are too generalized and based only on total amount of reinforcing steel $[24 \div 26]$, regardless of the pattern complexity which can greatly affect time needed for proper placing, tying and control. For example, patterns consisting of $11 \varnothing 16$, $8 \varnothing 18$ and $6 \varnothing 22$ bars, respectively, would all give approximately the same total amount of steel and consequently the same theoretical amount of man-hours, although it is obvious that such result would not be realistic. This conclusion was confirmed by the field research (described in the following section) that showed that variation of only $3 \%$ in total amount of steel can result in changes of as much as $50 \%$ in real amount of labour (time) and thus strongly affect the accurate estimation of number of man-hours and required number of rebar fixers, which are both important parameters in dynamics plans making. Besides that, productivity rates can significantly wary from country to country $[27 \div 29]$.

\section{Field research and results}

In order to develop adequate quantitative method for evaluating applicability of any given reinforcement pattern in reality, a field research was carried out with the aim of gathering data about real time needed for placing and fixing reinforcement in different formations. The research was based on preliminary results of the pilotstudy presented in [30].

\subsection{Research methodology}

The field research included 27 randomly chosen rebar fixers on nine on-going construction sites. Since the columns, slabs and walls are usually uniformly reinforced, the research was focused on reinforced concrete beams, where diversity considering the number of different diameters and patterns is more evident and quite common. The time was not measured only for placing the whole sets of bars in designed reinforcement patterns, but also for single bars and rows. In order to develop numerical comparison criteria, the results were normalized by dividing the obtained time by amount of steel per bar, row and the whole pattern respectively and thus transformed into man-hours.

Afterwards, it was necessary to recognize and define pattern features which have the most significant influence on man-hours and to develop adequate functional correlations that would describe them by comparable numerical values. In order to achieve that, obtained results were further normalized with respect to the average time needed for the 'unit pattern', i.e. the simplest pattern, consisting of two bars in the bottom row.

The functional correlations were developed for 72 patterns (treatment group) randomly chosen out of 90 obtained, while the remaining 18 were used as a control group. All obtained results and correlations were analyzed and processed using analysis of variance (ANOVA), Pearson correlation and the Scheffé method. 


\subsection{Results}

Comparison of data obtained in the field research confirmed logical assumption that the time needed for placing and fixing is affected by the following reinforcement pattern features: number of rows; number of bars per row; number of bars in the last row; number of different bar diameters used in the same cross-section; presence of bundles and their complexity.

In order to develop functional correlations that would separately describe these reinforcement pattern features, obtained data were divided into three categories: homogeneous patterns (consisting of single bars with the same diameter); heterogeneous patterns (consisting of single bars with different diameters); patterns with bundles.

Each pattern feature can be taken into account and described by the adequate partial coefficient which describes that feature's impact on complexity of a given pattern, i.e. on total amount of work (time) needed for placing and fixing. All of them are included in reinforcement pattern coefficient that is given as a product of all partial coefficients.

\subsection{Coefficient of distribution}

Coefficient of distribution $\left(c_{\mathrm{d}}\right)$ describes spatial distribution of reinforcement bars within a given cross section, i.e. number of rows $\left(n_{\mathrm{r}}\right)$ and number of bars per row $\left(n_{\mathrm{b}}\right)$ as well as the correction if the number of bars in the last row $\left(n_{\mathrm{bl}}\right)$ is not the same as in the other rows, and can be calculated as:

$c_{\mathrm{d}}=\left(a n_{\mathrm{r}}^{2}+b n_{\mathrm{r}}+c\right) \times 10^{-3}$,

where:

$$
\begin{aligned}
& a=-25-5 n_{\mathrm{b}}, \\
& b=825+115 n_{\mathrm{b}}-10 n_{\mathrm{bl}}, \\
& c=-110\left(n_{\mathrm{b}}-n_{\mathrm{bl}}\right) .
\end{aligned}
$$

If the last (highest) row is full, i.e. the same as the other rows, then $n_{\mathrm{bl}}=n_{\mathrm{b}}$.

Graph in Fig. 1 shows comparison of results for patterns consisting of 2-4 rows with 2-5 bars per row calculated by this approximation (full lines) and the results obtained at the building sites (points). Although it might be expected that the graph would have linear character (which would be logical and theoretically acceptable if we do not consider human behaviour factor), presented graph is slightly non-linear and can be better approximated with quadratic curve than the straight line. This can be explained by the 'learning curve' effect [31], as well as by the Hawthorne effect [32] (people tend to work faster/better when they are aware of the fact that somebody is measuring and assessing their productivity), although the latter one is questionable and still a subject of discussions in scientific circles [33].

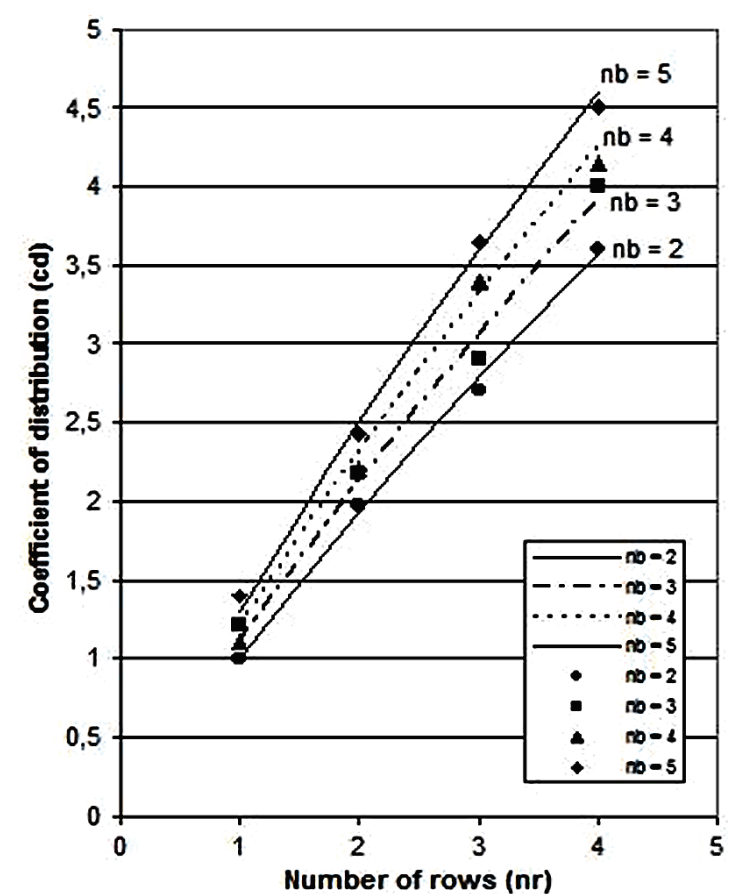

Figure 1 Coefficient of distribution $\left(c_{\mathrm{d}}\right)$, real and approximated values

\subsection{Coefficient of uniformity}

Coefficient of uniformity $\left(c_{\mathrm{u}}\right)$ describes number of different bar diameters or types of bundles used in a given cross section $\left(n_{\mathrm{d}}\right)$ and can be calculated as:

$c_{\mathrm{u}}=0,90+0,10 n_{\mathrm{d}}$.

Slight increase of time in comparison with the uniform reinforcement pattern $\left(n_{\mathrm{d}}=1\right)$ was expected and can be explained by higher level of concentration and attention needed for placing different bars or bundles in their assigned formation.

\subsection{Coefficient of complexity}

Coefficient of complexity $\left(c_{\mathrm{c}}\right)$ includes additional work needed if the reinforcement bundles have to be made. It was noticed that number of bars per bundle (two, three or four) does not significantly impact the total time needed for making the bundle and placing it in its proscribed position. The only significant factor was the bundle homogeneity, i.e. if it consists of same or different bars. Consequently, coefficient of complexity is not given as a function but as a set of discrete values:

- $\quad c_{\mathrm{c}}=1,00$, if only single bars are used (no bundles);

- $\quad c_{\mathrm{c}}=1,10$, if the bundles are homogeneous (consisting of same bars);

- $\quad c_{\mathrm{c}}=1,15$, if the bundles are heterogeneous (consisting of different bars).

\subsection{Reinforcement pattern coefficient}

Total reinforcement pattern coefficient $\left(C_{\mathrm{r}}\right)$ includes all the partial coefficients and can be calculated as:

$C_{\mathrm{r}}=c_{\mathrm{d}} c_{\mathrm{u}} c_{\mathrm{c}}$ 
Formulated in this way, pattern coefficient can be included in calculation as additional decision-making criteria, both in the designing process or the optimality analysis. Even if the objective function does not include the labour price, reinforcement pattern coefficient can be used as a comparison criterion for applicability assessment of different reinforcement patterns with the same or approximately same bearing capacity or amount of steel. Besides that, pattern coefficient can also be used as a correctional coefficient for obtaining more realistic results in calculation of man-hours and for dynamics plans making.

\section{Examples and discussion}

Applicability of presented coefficients will be illustrated by two examples. In the first one, possibility of forming bundles is not considered because the emphasis is on remarkable changes in amount of time needed for placing and fixing that can be achieved by very small variations of the reinforcement. On the other hand, the second example presents various possibilities for creating and combining bundles in order to show that one set of bars can be arranged in numerous feasible patterns and that, therefore, optimality criteria should not be limited to the minimal amount of steel or bearing capacity but should also include applicability of a given solution in practice.

\subsection{Example 1}

The first example (Fig. 2) presents several different feasible solutions for the problem proposed by Govindaraj and Ramasamy [21]. For rectangular cross section with optimal dimensions $b / h=25 / 32,5 \mathrm{~cm}$, calculated required area of steel is $9,32 \mathrm{~cm}^{2}$ and the next step is finding adequate reinforcement pattern, i.e. number, diameters and formation of bars that would provide total area of steel greater than or equal to the calculated value.

Solution a), proposed by the authors of [21], is obtained by the genetic algorithm in which the only criterion for the reinforcement pattern is minimal necessary amount of steel for required bearing capacity. Although this solution is mathematically the best one, its applicability from the practical point of view is questionable because the proposed pattern is relatively complicated (consisting of three different diameters), which is confirmed by value $C_{\mathrm{r}}=2,56$.

The second best solution $(b)$ requires insignificantly larger amount of steel $\left(\Delta_{\mathrm{A}}=0,64 \%\right)$ but it is much simpler for producing and requires $8,98 \%$ less time than the first one. However, without introducing applicability assessment of a given pattern as an additional criterion, this solution would be eliminated as non-optimal although it is much more preferable from the practical point of view.

Solution c) is even more interesting because it requires only $3,52 \%$ more reinforcement than the first one but remarkably less time for placing - almost half as much as the best solution $\left(\Delta_{C}=48,44 \%\right)$. This solution is obtained under the same conditions as the first two, but with including reinforcement pattern coefficient as additional criterion.
On the other hand, in traditional designing approach, without deeper analysis of possible reinforcement patterns and regardless of considering possibility of combining different diameters, a designer would probably opt for a uniform pattern consisting of bars with the same diameters. In that case, the most acceptable solution would be $5 \varnothing 16\left(A_{\mathrm{r}}=10,05 \mathrm{~cm}^{2}\right)$. However, since $5 \varnothing 16$ cannot be placed in one row (cross-section is too narrow for that), the most probable option would be d). This solution requires $7,37 \%$ more reinforcement and 20,7\% less time than the best one, while in comparison with solution c) it requires $3,71 \%$ more reinforcement but as much as $53,78 \%$ more time.

This example shows that proper choice of the reinforcement diameters and pattern can significantly affect not only the price of a given structure but also the amount of time required for its making at the building site. This fact also proves the hypothesis that structural design should not be considered only from the mathematical or economical point of view, but also as an engineering problem that demands experience and practical knowledge of the matter.
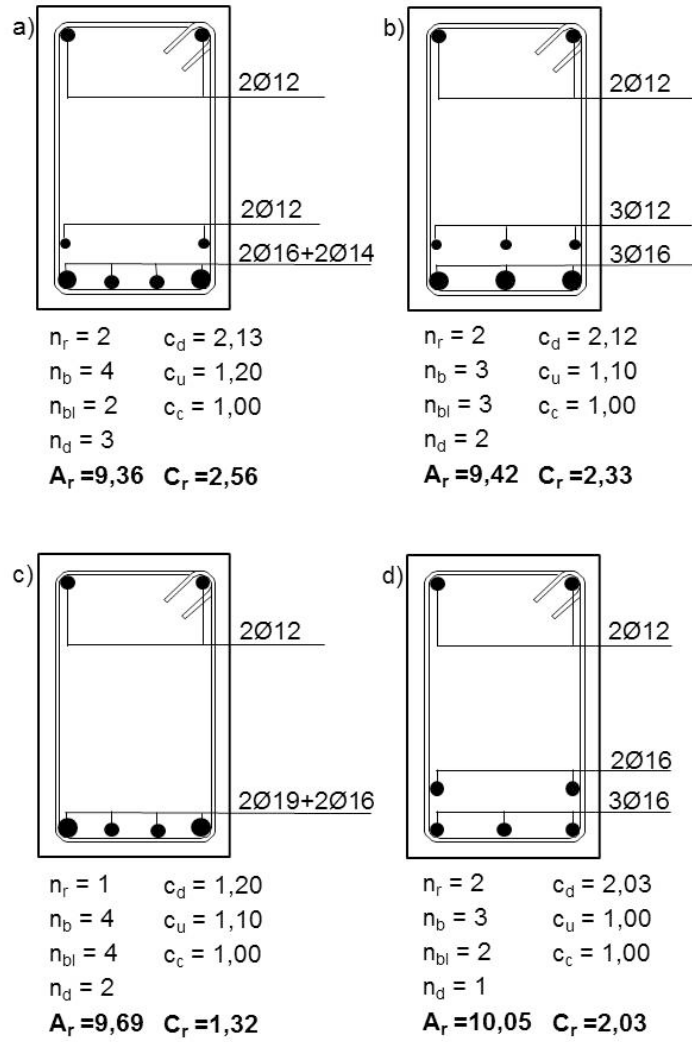

Figure 2 Example 1: feasible reinforcement patterns for rectangular cross section $b / h=25 / 32,5 \mathrm{~cm}$ and required steel area $A_{\mathrm{r}}=9,32 \mathrm{~cm}^{2}$

\subsection{Example 2}

The second example, presented in Fig. 3, illustrates how reinforcement pattern coefficient can be useful when a designer (or computer) is supposed to choose one of several reinforcement formations consisting of the same bars. Cross-sectional dimensions are $b / h=30 / 75 \mathrm{~cm}$ and calculated required amount of steel is $A_{\mathrm{r}}=58,86 \mathrm{~cm}^{2}$. All presented patterns consist of $12 \varnothing 25\left(58,91 \mathrm{~cm}^{2}\right)$, with approximately equal bearing capacity. In the next step, a 
designer or computer is supposed to choose the most appropriate, i.e. optimal reinforcement pattern.

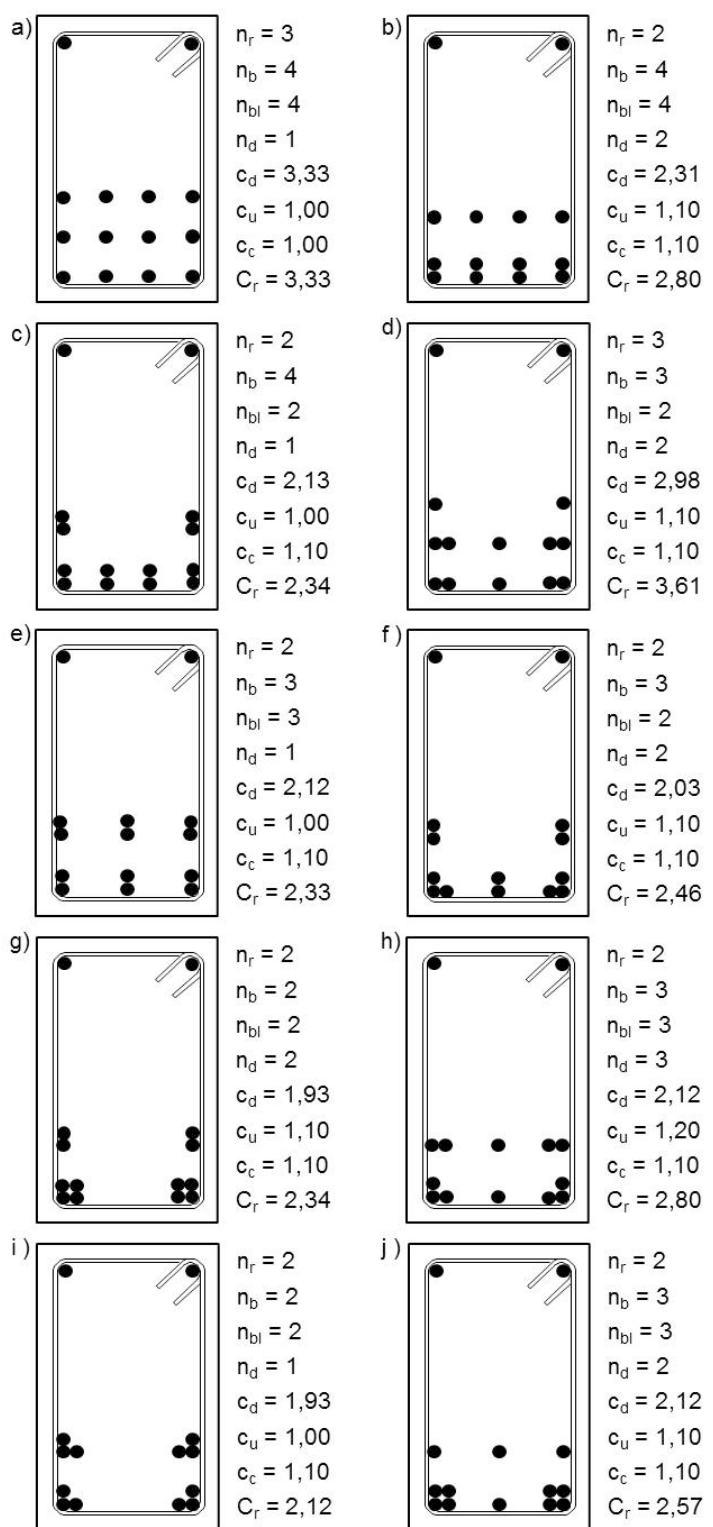

Figure 3 Example 2: feasible reinforcement patterns for rectangular cross section $b / h=30 / 75 \mathrm{~cm}$ and required steel area $A_{\mathrm{r}}=58,86 \mathrm{~cm}^{2}$

Since all proposed patterns consist of the same set of bars, total amount of steel cannot be taken as the optimality criterion. Although bearing capacity might be helpful in decision making, in this case it would not be adequate criterion because all solutions are feasible, i.e. all of them have sufficient bearing capacity. Because of that, computer would not be able to make a difference between proposed possibilities in order to recommend one as the 'optimal'. Furthermore, even an experienced designer would have difficulty in estimating applicability of proposed solutions. However, including reinforcement pattern coefficient as the optimality criterion would make the decision-making process much easier, because it is obvious that solution i) requires the smallest amount of time for placing and fixing the bars without compromising the bearing capacity.

This example, as well as the previous one, shows that man-hours calculation should not be based only on total amount of steel because different reinforcement formations, even when consisting of same bars, simply cannot be considered as equivalents [34]. Because of that, reinforcement pattern coefficient can be helpful in both the traditional design process and the optimization software tools such as [35].

\section{Conclusion}

Adequate choice of the reinforcement pattern is an important step in design of the reinforced concrete structures and therefore should not be based only on intuition. Applicability of any given reinforcement pattern should be considered during the design process because it can significantly affect the amount of time required for placing and fixing at the building site. Field research showed that norms for productivity rates for in-situ reinforcement fixing are too generalized and that calculation of man-hours based only on total amount of reinforcing steel is not realistic. Besides that, total computer-based optimization would be possible only if we find a way to 'teach' computer how to make distinction between similar reinforcement patterns and to imitate reasoning of an experienced designer.

In order to find correlations between different reinforcement pattern features and the real time needed for placing and fixing, a field research was carried out at nine on-going building sites. Obtained data were normalized and processed and all relevant aspects of the reinforcement pattern were described using partial coefficients of distribution, uniformity and complexity.

All partial coefficients are included in the reinforcement pattern coefficient that describes relative time needed for placing and fixing any given formation of the reinforcement bars. Testing on different problems showed that proposed estimation method can successfully be used in both the traditional design process and computer-based design and optimization methods.

\section{References}

[1] Chakrabarty, B. K. Models for optimal design of reinforced concrete beams. // Computers and Structures. 42, 3(1992), pp. 447-451.

[2] Coello Coello, C. A.; Christiansen, A. D.; Santos Hernandez, F. A Simple genetic algorithm for the design of reinforced concrete beams. // Engineering with Computers. 13, (1997), pp. 185-196.

[3] Ferreira, C. C.; Barros, M. H. F. M.; Barros, A. F. M. Optimal design of reinforced concrete T-sections in bending. // Engineering Structures. 25, 7(2003), pp. 951964.

[4] Barros, M. H. F. M.; Martins, R. A. F.; Barros, A. F. M. Cost optimization of singly and doubly reinforced concrete beams with EC2-2001. // Structural and Multidisciplinary Optimization. 30, (2005), pp. 236-242.

[5] Guerra, A.; Kiousis, P. Design optimization of reinforced concrete structures. // Computers and Concrete. 3, 5(2006), pp. 313-334.

[6] Perera, R.; Vique, J. Strut-and-tie modelling of reinforced concrete beams using genetic algorithms optimization. // Construction and Building Materials. 23, (2009), pp. 29142925.

[7] Barros, A. F. M.; Barros, M. H. F. M.; Ferreira, C. C. Optimal design of rectangular RC sections for ultimate bending strength. // Structural and Multidisciplinary Optimization. 45, (2012), pp. 845-860. 
[8] Matouš, K.; Lepš, M.; Zeman, J.; Šejnoha, M. Applying genetic algorithms to selected topics commonly encountered in engineering practice. // Computer Methods in Applied Mechanics and Engineering. 190, 13-14(2000), pp. 1629-1650.

[9] Lepš, M. And Šejnoha, M. New approach to optimization of reinforced concrete beams. // Computers \& Structures. 81, 18-19(2003), pp. 1957-1966.

[10] Koumousis, V. K.; Arsenis, S.J. Genetic algorithms in optimal detailed design of reinforced concrete members. // Computer Aided Civil Infra-structure Engineering. 13, (1998), pp. 43-52.

[11] Yokota, T.; Wada, S.; Taguchi, T.; Gen, M. GA-based Method for a Single Reinforced Concrete Beam Optimal T Cross Section Design Problem Using the Ultimate Strength. // Proceedings of the Fifth Asia Pacific Industrial Engineering and Management Systems Conference 2004. I CD, pp. 32.10.1-32.10.9.

[12] Bekdas, G.; Nigdeli S. M. Cost Optimization of T-shaped Reinforced Concrete Beams under Flexural Effect According to ACI 318. // Proceedings of the $3^{\text {rd }}$ European Conference of Civil Engineering / ECCIE '12, pp. 122-126.

[13] Jahjouh, M. M.; Arafa, M. H.; Alqedra, M. A. Artificial Bee Colony $(\mathrm{ABC})$ algorithm in the design optimization of RC continuous beams. // Structural and Multidisciplinary Optimization. 47, 6(2013), pp. 963-979.

[14] Alqedra, M. A.; Mohammed, I. Optimum Cost of Prestressed and Reinforced Concrete Beams using Genetic Algorithms. // Journal of Artificial Intelligence. 4, (2011), pp. 76-88.

[15] Rajeev, S.; Krishnamoorthy, C. S. Genetic algorithm-based methodology for design optimization of reinforced concrete frames. // Computer-Aided Civil Infrastructure Engineering, 13, (1998), pp. 63-74.

[16] Camp, C. V.; Pezeshk, S. and Hansson, H. Flexural design of reinforced concrete frames using a genetic algorithm. // Journal of Structural Engineering. 129, (2003), pp. 105115.

[17] Lee, C.; Ahn, J. Flexural design of reinforced concrete frames by genetic algorithm. // Journal of Structural Engineering. 129, (2003) pp. 762-774.

[18] Kwak, H. G.; Kim J. Optimum design of reinforced concrete plane frames based on predetermined section database. // Computer Aided Design. 40, 3(2008), pp. 396408.

[19] Kwak, H.G.; Kim J. An integrated genetic algorithm complemented with direct search for optimum design of RC frames. // Computer Aided Design. 41, (2009), pp. 490-500.

[20] Kaveh, A.; Sabzi, O. A comparative study of two metaheuristic algorithms for optimum design of reinforced concrete frames. // International Journal of Civil Engineering. 9, 3(2011), pp. 193-206.

[21] Govindaraj, V.; Ramasamy, J. V. Optimum detailed design of reinforced concrete continuous beams using genetic algorithms. // Computers and Structures. 84, (2005), pp. 3448.

[22] Govindaraj, V.; Ramasmy J. V. Optimum detailed design of reinforced concrete frames using genetic algorithms. // Engineering Optimisation. 39, 4(2007), pp. 471-494.

[23] Yousif S. T.; Najem R. M. Optimum cost design of reinforced concrete continuous beams using Genetic Algorithms. // International Journal of Applied Sciences and Engineering Research. 2, 1(2013), pp. 79-92.

[24] Mijatović, R.; Norms and Standards in Civil Engineering, Book 2 (in Serbian), Građevinska knjiga, Belgrade, 2008.

[25] Pratt, D. Fundamentals of Construction Estimating, Cengage Learning, 2003.

[26] Page, J. S. Estimator's General Construction Man-hour Manual, Gulf Professional Publishing, 1977.
[27] Proverbs, D.; Holt, G. D.; Olomolaiye, P. The management of labour on high rise construction projects: An international investigation. // International Journal of Project Management. 17, 3(1999), pp. 195-204.

[28] Proverbs, D.; Holt, G. D.; Olomolaiye, P. A method for estimating labour requirements and costs for international construction projects at inception. // Building and Environment. 34, 1(1999), pp. 43-48.

[29] Proverbs, D.; Holt, G. D.; Olomolaiye, P. A comparative evaluation of planning engineers' formwork productivity rates in European construction. // Building and Environment. 33, 4(1998). pp. 181-187.

[30] Milajić, A.; Beljaković, D.; Pejičić, G. Optimal reinforced concrete beams design using hybrid GA-TABU algorithm. // Technics Technologies Education Management. 8, 2(2013), pp. 533-540.

[31] Zangwill, W. I.; Kantor, P. B. Toward a Theory of Continuous Improvement and the Learning Curve. // Management Science. 44, 7(1998), pp. 910-920.

[32] Draper, S. W. The Hawthorne, Pygmalion, Placebo and other effects of expectation: some notes, 2010. http://www.psy.gla.ac.uk/ steve/hawth.html (17.07.2013.)

[33] Olson, R.; Verley, J.; Santos, L.; Salas, C. What we teach students about the Hawthorne studies: A review of content within a sample of introductory I-O and OB textbooks. // The Industrial-Organizational Psychologist. 41, 3(1994). pp. 23-39.

[34] Milajić, A.; Beljaković, D.; Petronijević, P. Genetic algorithms for assigning tasks to construction machine operators. // Građevinar. 63, 8(2011), pp. 749-755.

[35] Džakić, D.; Kraus, I.; Morić, D. Direct displacement based design of regular concrete frames in compliance with Eurocode 8. // Tehnicki vjesnik-Technical Gazette. 19, 4(2012), pp. 973-982.

\section{Authors' addresses}

Doc. dr. sc. Aleksandar Milajić

Faculty of Construction Management

Union - Nikola Tesla University

Cara Dušana 72-74, 11000 Belgrade, Serbia

E-mail: aleksandar.milajic@gmail.com

Prof. dr. sc. Aleksandar Prokić

Faculty of Civil Engineering Subotica

Kozaračka 2a, 24000 Subotica, Serbia

E-mail: aprokic@EUnet.yu

Doc. dr. sc. Dejan Beljaković

Faculty of Construction Management

Union - Nikola Tesla University

Cara Dušana 72-74, 11000 Belgrade, Serbia

E-mail:beljak@mail.com

Mr. sc. Goran Pejičić

European University Brčko District

Bulevar Mira br.4/III, IV, Brčko District, Bosnia and Herzegovina E-mail: gpejicic@gmail.com 